\title{
SHRIMP dating of titanite from metasyenites in the Central Zone of the Limpopo Belt, South Africa
}

\author{
Rigby, M.J. ${ }^{1} 2^{2 *} \&$ Armstrong, R.A. ${ }^{3}$ \\ ${ }^{1}$ Department of Geology, University of Pretoria, Lynwood Road, Pretoria, 0002, South Africa. \\ ${ }^{2}$ Runshaw College, Langdale Road, Leyland, Lancashire, PR25 3DQ, UK. \\ ${ }^{3}$ Research School of Earth Sciences, The Australian National University, Mills Road, Canberra, 0200, ACT,
}

Australia.

\begin{abstract}
SHRIMP dating of titanite from metasyenites in the Central Zone of the Limpopo Belt yields a mean ${ }^{207} \mathrm{~Pb} /{ }^{206} \mathrm{~Pb}$ age of $2010.3+/-4.5 \mathrm{Ma}$ calculated from twenty-three analyses. This age, combined with petrographic and field observations, suggests the metamorphism in the syenites occurred during the regional Palaeoproterozoic event.
\end{abstract}

Keywords: Limpopo Belt; SHRIMP; titanite; geochronology; Palaeoproterozoic.

\section{Introduction}

A unique body of (meta)-syenite intrudes the Alldays Gneiss and outcrops in an elongate, $6.25 \times 1.25 \mathrm{~km}$ body WNW of Alldays within the Central Zone of the Limpopo Belt, South Africa (Fig 1a + b). A recent study by Rigby et al. (2008a) reveals the metasyenites underwent a metamorphic evolution characterized by a maximum pressure of 7-8 kbar and $\sim 770^{\circ} \mathrm{C}$. The subsequent retrograde path involved a simultaneous P-T decrease along a decompression-cooling path to $4 \mathrm{kbar}$ and $\sim 550^{\circ} \mathrm{C}$. These P-T estimates are 'intermediate' between the high-grade conditions reported by Zeh et al. (2004) and Rigby (2009) for metapelites near Messina and the amphibolite-facies conditions reported by Zeh et al. (2005a,b) and Chudy et al. (2008) for rocks from the Venetia area. Collectively, this data led Rigby et al. (2008a) to postulate the existence of a metamorphic field gradient. However, there are two main tectonometamorphic episodes known in the Central Zone of Limpopo Belt, one in the Neoarchean (e.g. McCourt \& Armstrong, 1998; Kroner et al., 1998; Bumby et al., 2001; Bumby \& van der Merwe, 2004; Zeh et al., 2007; Millonig et al., 2008; Perchuk et al., 2008; Van Reenen et al., 2008; Gerdes \& Zeh, 2009; Zeh et al. 2009) and one in the Palaeoproterozoic (e.g. Jaeckel et al., 1997; Holzer et al., 1998; Kroner et al., 1999; Zeh et al., 2004; Rigby et al., 2008b; Chudy et al., 2008; Eriksson et al., 2009; Gerdes \& Zeh, 2009; Rigby et al., 2010; Eriksson et al., 2010a and b; Millonig et al., 2010) and without robust geochronological constraints it is not clear in which event the metasyenites were metamorphosed. Additionally, due to this uncertainty, the existence of the proposed metamorphic field gradient by Rigby et al (2008a) is, at present, mere speculation. In this short communication we present new U-Pb SHRIMP data obtained from titanite in the metasyenites to delineate their age and support the metamorphic field gradient hypothesis. 

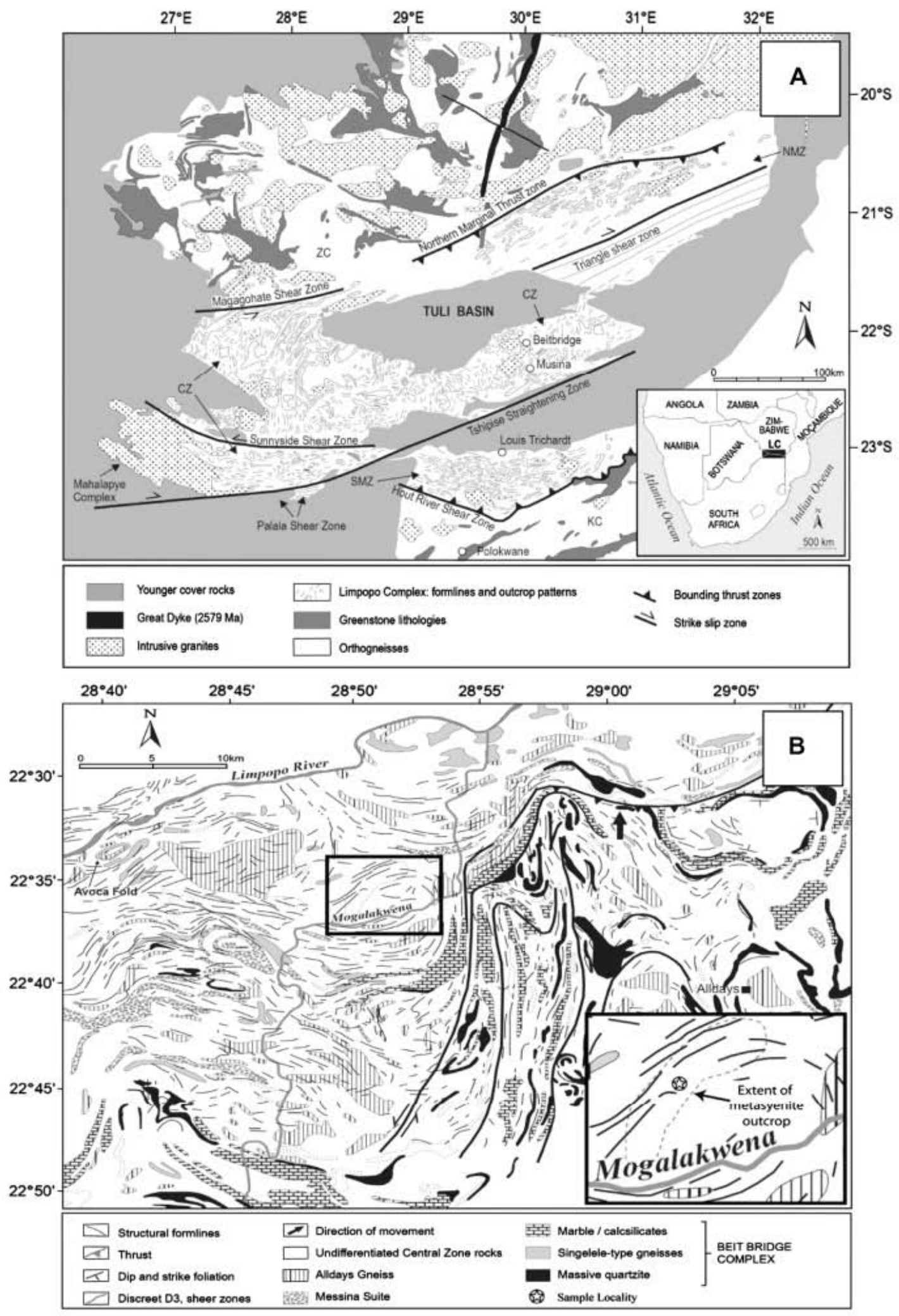

Fig. 1. (A) A map of the Limpopo Belt (after Boshoff et al. (2006)). (B) A detailed geological map of the field area (after Boshoff et al. (2006) and Rigby et al. (2008a)). 


\section{Geological Context \\ Regional}

The Limpopo Belt of southern Africa (Fig. 1a) is a predominantly high-grade terrane composed of three distinct zones, each with a distinctive geological history and tectonometamorphic evolution. The Southern Marginal Zone (SMZ) represents a high-grade equivalent of the granite-greenstone successions that prevail in the adjacent Kaapvaal Craton (KC). The SMZ is separated from the $\mathrm{KC}$ by the inward-dipping strike-slip ductile shear zone known as the Hout River Shear Zone. Similarly, the Northern Marginal Zone (NMZ) is a high-grade equivalent of the Zimbabwe Craton, which is separated from the NMZ by the North Limpopo Thrust Zone. Conversely, the Central Zone (CZ) forms a unique and distinct supracrustal block, which is bound to the north and south by the Magohapote and Triangle Shear Zone and Zoefontein-Palala Shear Zones respectively. The P-T-t evolution of the CZ of the Limpopo Belt is a vast and contentious issue too lengthy to be discussed here, however, the reader is referred to Perchuk et al. (2008), Zeh \& Klemd (2008) and Rigby (2009) and references therein for a comprehensive description and discussion of this topic.

\section{Local}

The metasyenites outcrop within the farms of Rietfontein $217 \mathrm{MR}$ and Mietjiesfontein $220 \mathrm{MR}$, approximately $25 \mathrm{~km}$ W-N-W of Alldays (S22 $35^{\prime} 19.2^{\prime \prime}$ EO28 50 ' 12.4 ") (inset Figure 1B). Field relationships indicate the (meta)syenites intruded into the Alldays gneiss (Brandl \& Pretorious, 2000). In hand-specimen the metasyenite is a coarsegrained, crystalline rock composed primarily of K-feldspar, quartz and amphibole. The amphiboles are aligned forming a weak but macroscopically-prominent foliation that strikes approximately NE-SW and dips steeply towards the NW. The metasyenites also contain 20-30 cm-scale, asymmetric folds that have fold-axes trending NW-SE. A large number of quartzo-feldspathic veins, interpreted to represent mobilized melt from the surrounding Alldays gneisss, cross-cut the metasyenite and manifest in various forms; (1) as single, linear veins measuring from $0.2 \mathrm{~cm}-30 \mathrm{~cm}$ in diameter (2) as linear conjugate pairs intersecting at $\sim 60 / 120^{\circ}$ measuring up to $15 \mathrm{~cm}$ in diameter (3) as folded veins measuring up to $10 \mathrm{~cm}$ in diameter (Figure 2A) (4) as linear veins, offset by small-scale normal faults and (5) as inter-connected, mesh-like networks (Rigby et al. 2008a).

\section{Samples \& Methodology}

Sample description

The rock contains amphibole in two distinct textural settings; (1) weakly aligned, parallel prismatic grains measuring up to $8 \mathrm{~mm}$ in length that form a weak foliation. (2) as randomly oriented blocky grains measuring up to $4 \mathrm{~mm}$ in diameter. The amphiboles are set in a coarse grained, inter-locking crystalline matrix consisting of predominantly Kfeldspar with interstitial clinopyroxene, plagioclase, quartz, titanite and magnetite (Figure 2B). K-feldspar forms randomly oriented, euhedral-blocky grains, measuring up $10 \mathrm{~mm}$ in diameter and commonly exhibiting micro-perthitic exsolution textures. Plagioclase and K-feldspar show signs of sericitization. Quartz, commonly exhibiting sub-grain development, is found only in contact with $\mathrm{K}$-feldspar and plagioclase where it forms relatively small $(<2 \mathrm{~mm})$ interstitial patches between the blocky grains. Clinopyroxene forms randomly oriented subhedral-euhedral grains that are interstitial between large 

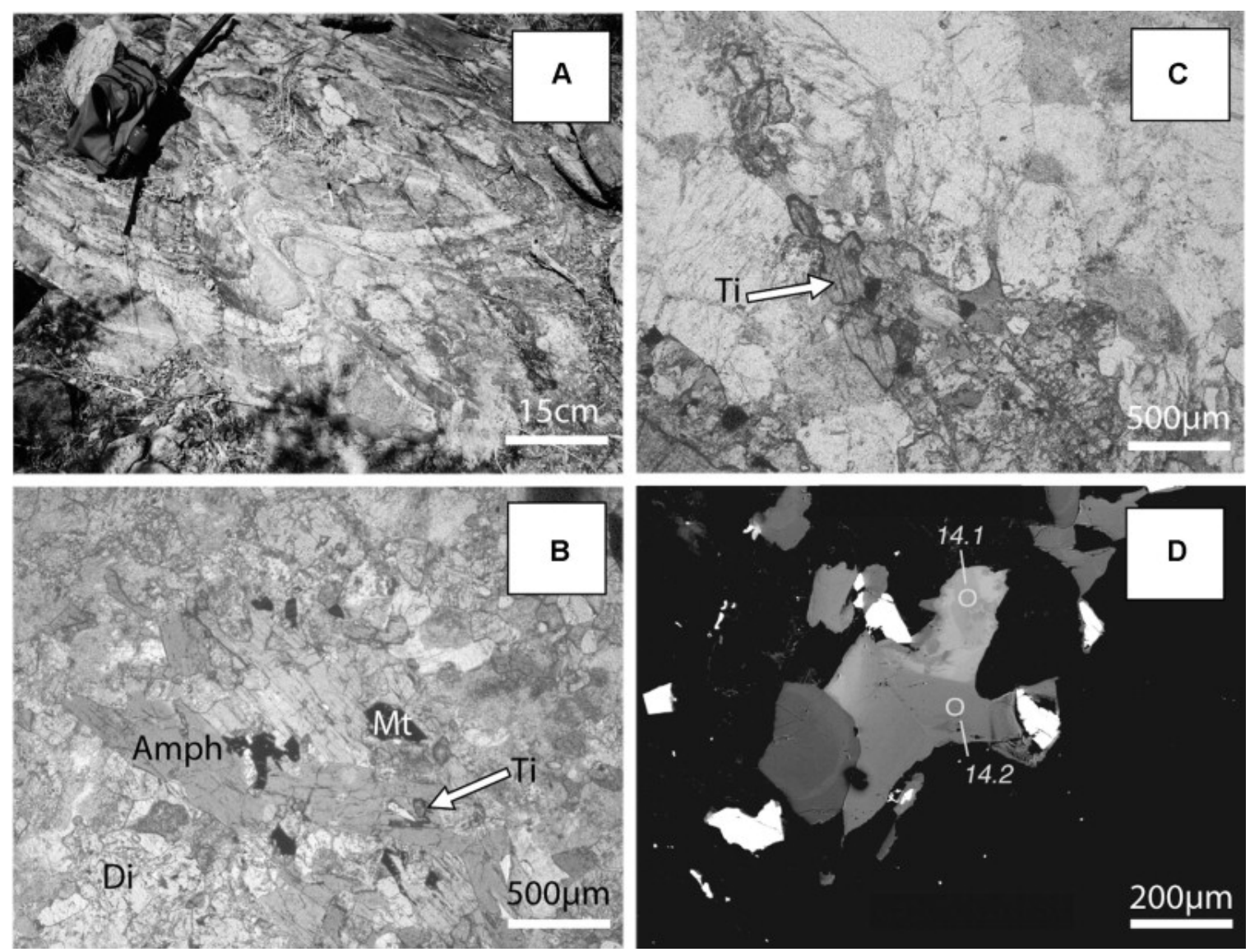

Fig. 2. (A) Field photograph small-scale folding within the metasyenite. (B) Photomicrograph of the thinsection RM06/49 illustrating the mineral assemblage (Amph = amphibole; $\mathrm{Di}=$ clinopyroxene; $\mathrm{Ti}$ = titanite; $\mathrm{Mt}=$ magnetite. $(\mathrm{C})$ Photomicrograph of the thin-section RM06/49 illustrating large elongate titanites. (D) BSE image illustrating the zoning/internal structure of a single titianite grain.

blocky K-feldspars and elongate amphibole. Magnetite forms small equant grains measuring up to $0.5 \mathrm{~mm}$ in diameter, which are commonly located in contact with, or immediately adjacent to the amphiboles. Titanite is the most abundant accessory mineral, forming both large $(>5 \mathrm{~mm})$ subhedral-to-euhedral grains (Figure $2 \mathrm{C}$ ) and randomly oriented clusters composed of several small grains $(0.1-1 \mathrm{~mm})$.

\section{Methodology}

Photomicrographs in transmitted and reflected light were taken of the titanite thinsections and together with back-scattered electron (BSE) images, were used to delineate the internal structures of the sectioned grains and to target specific areas within the minerals for spot analyses. BSE images of titanite reveal that specific domains of an individual grain have a contrast in the grey-scale, which may indicate compositional zoning (Figure 2D). U-Pb analyses of titanite were performed in situ from several thinsections of the same sample at the Research School of Earth Sciences (RSES), Australian National University using a SHRIMP II. Uncertainties given for individual analyses (ratios and ages; Table 1) are at the $1 \sigma$ level, whereas uncertainties in the calculated weighted mean ages are reported at $95 \%$ confidence limits and include the uncertainties 
in the standard calibration. Concordia plots and weighted mean age calculations were carried out using Isoplot/Ex (Ludwig 1999). Concordia ages were calculated using the SQUID Excel macro (Ludwig 2000) with uncertainties from the standard calibration included in the final errors quoted. On the basis of previous studies, the quadratic relationship between $\mathrm{Pb}^{+} / \mathrm{U}^{+}$and $\mathrm{UO}^{+} / \mathrm{U}^{+}$(Claoue'-Long et al. 1995) used for zircon also provides a good first-order correction for the interelement fractionation in the ion emission from titanite (Williams, 1998).

\section{Results and Discussion}

Twenty-three analyses from different titantite grains were undertaken and the results are presented in table 1 . The concordia plot (Figure 3) demonstrates most analyses are concordant. Intercepts occur at $2012+/-14 \& 64+/-560$ Ma with a MSWD of 0.38 . The data yields a precise calculated mean ${ }^{207} \mathrm{~Pb} /{ }^{206} \mathrm{~Pb}$ age of $2010.3+/-4.5 \mathrm{Ma} \cdot{ }^{207} \mathrm{~Pb} /{ }^{206} \mathrm{~Pb}$ ages range from $1996.4+/-9.6$ to $2057+/-49 \mathrm{Ma}$ and there is no discernible age difference between different zones within a single titanite grain.

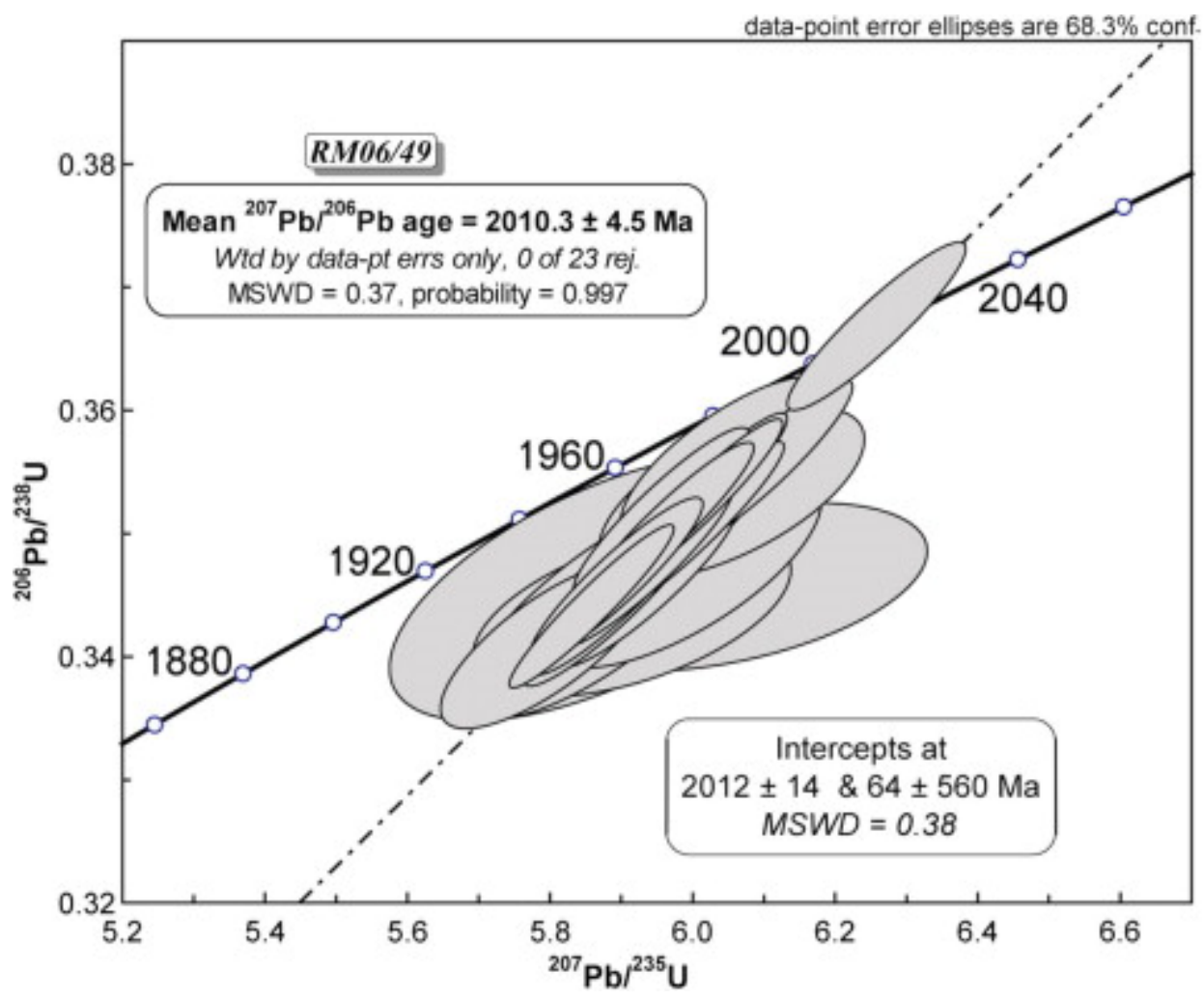

Fig. 3. U-Pb Concordia diagram for sample RM06/49.

The calculated mean ${ }^{207} \mathrm{~Pb} /{ }^{206} \mathrm{~Pb}$ age of $2010.3+/-4.5 \mathrm{Ma}$ suggests the titanite formed during the Paleoproterozoic event and is agreement with the data from the following studies: Chudy et al. (2008) who determined U-Pb dating of monazite yields an age of 2015 +/- 8Ma; Pb stepwise leaching data obtained by Holzer et al. (1998) from garnet and titanite, which yield ages of $2010 \pm 17 \mathrm{Ma}$ and $2007 \pm 5 \mathrm{Ma}$, respectively; Zircon ages from Gerdes \& Zeh (2009) at 2021 +/- 10 Ma and Van Reenen et al. (2008) who dated 
syntectonic anatectic material by U-Pb monazite $(2017.1 \pm 2.8 \mathrm{Ma})$ and $\mathrm{PbSL}$ garnet (2023 $\pm 11 \mathrm{Ma})$.

The experiments of Cherniak (1993) indicate that titanite with a diffusion domain radii of 0.005 to $0.5 \mathrm{~cm}$ should close to $\mathrm{Pb}$ diffusion between 650 and $780^{\circ} \mathrm{C}$, respectively, for cooling rates typical of regional metamorphism. The studied titanite grains form crystals up to $0.5 \mathrm{~cm}$ in radius, compatible with a closure temperature of $780^{\circ} \mathrm{C}$ (Cherniak 1993); a temperature which is in agreement with the peak metamorphic conditions determined from pseudosections and conventional thermobarometry by Rigby et al. (2008a) and may suggest the titanite formed during metamorphism. Conversely, Rigby et al. (2008a) suggest that the titanites were part of the primary magmatic assemblage and that metamorphism of the syenite was not associated with neo-mineralization. Prior to the experiments of Cherniak (1993) titanite was deemed to have a very low closure temperature as it recrystallizes easily during deformation (e.g. Mezger et al. 1991). Therefore it can date deformation even under low grade conditions. In the present case the most likely interpretation is therefore that the titanite dates the tectonometamorphic episode at c. $2.0 \mathrm{Ga}$. Irrespective of arguments pertaining to closure temperatures, the data does constrain the age of the metamorphism irrespective of the whether the titanites are magmatic or metamorphic in origin. If the titanites are metamorphic in origin then the data defines a precise growth age. Alternatively, if the titanites are magmatic then the SHRIMP data, coupled with field observations and petrographic data that indicate the metasyenites are deformed, define a minimum-age constraint on the Paleoproterozoic event. Moreover, the P-T conditions determined by Rigby et al. (2008a) to be 'intermediate' between the amphibolite facies conditions reported by Zeh et al. (2005a) and the granulite facies conditions of Zeh et al. (2004) and Rigby (2009) are now bracketed in terms of their age, and collectively this data may suggest that the metamorphic field gradient hypothesis proposed by Rigby et al. (2008a) is a valid concept and that metamorphic conditions across the Central Zone of the Limpopo Belt at $2.0 \mathrm{Ga}$ varied predictably. However, this hypothesis is dependent on the reliability of the P-T conditions determined by different workers using different methods (Perchuk et al., 2008 versus Zeh \& Klemd, 2008 and Rigby, 2009). If the P-T estimates produced by the pseudosection approach (e.g. Zeh et al. 2004; 2005a; Rigby et al., 2008a and Rigby, 2009) are correct then the field gradient hypothesis remains a valid concept. However, if the local equilibrium estimates of Boshoff et al. (2006) and Perchuk et al. (2008) are correct then the hypothesis may be flawed. The debate over the P-T estimates is a contentious issue which has yet to be fully resolved. In regards to the 'field gradient' it is a working hypothesis and additional P-T-t work is required to further validate the concept.

\section{Conclusion}

A mean ${ }^{207} \mathrm{~Pb} /{ }^{206} \mathrm{~Pb}$ age of $2010.3+/-4.5 \mathrm{Ma}$ from titanite brackets the age of metamorphism in the syenites to have occurred during the regional Paleoproterozoic event. The age, when used in conjunction with other published data may suggest that the Central Zone of the Limpopo Belt preserves evidence of a metamorphic field gradient at c. $2.0 \mathrm{Ga}$. 


\section{Acknowledgements}

This research was supported by a University of Pretoria RDP grant. We would like to thank Pat Eriksson for his editorial handling and Jan Kramers for useful comments and a constructive review.

\section{References}

Boshoff, R., Van Reenen, D.D., Kramers, J. D., Smit, C.A., Perchuk, L.L., and Armstrong, R. 2006. Geologic History of the Central Zone of the Limpopo Complex: The West Alldays Area. The Journal of Geology, 114, 699-716.

Bumby, A.J., Eriksson, P.G., van der Merwe, R., and Brumer, J.J., 2001. Shear-zone controlled basins in the Blouberg area, Northern Province, South Africa: syn- and post-tectonic sedimentation relating to c. 2.0 Ga reactivation of the Limpopo Belt. Journal of African Earth Sciences, 33, 445-461.

Bumby, A.J. and van der Merwe, R., 2004. The Limpopo Belt of southern Africa: an overview. In: Tempos and events in Precambrian time. Elsevier, Amsterdam, 217-222.

Cherniak, D. J. 1993. Lead diffusion in titanite and preliminary results on the effects of radiation damage on $\mathrm{Pb}$ transport. Chem. Geol. 110:177-194.

Chudy, T.C., Zeh, A., Gerdes, A., Klemd, R. \& Barton, J.M., 2008. Palaeoarchaean (3.3Ga) mafic magmatism and Palaeoproterozoic $(2.02 \mathrm{Ga})$ amphibolite-facies metamorphism in the Central Zone of the Limpopo Belt: New geochronological, petrological and geochemical constraints from metabasic rock and metapelitic rocks from the Venetia area. South African Journal of Geology, 111, 3987-408.

Claoue' -Long, J. C.; Compston, W.; Roberts, J.; and Fanning,C. M. 1995. Two Carboniferous ages: a comparisonof SHRIMP zircon dating with conventional zircon ages and 40Ar/39Ar analysis. In Berggren,W. A., ed. Geochronology, time scales and global stratigraphic correlation. SEPM Spec. Publ. 54, p. 3-21.

Eriksson, P.G., Banerjee, S., Nelson, D.R., Rigby, M.J., Catuneanu, O., Sarkar, S., Roberts, R.J., Ruban, D., Mtimkulu, N.M. \& Sunder Raju, P.V. 2009. A Kaapvaal craton debate: nucleus of an early small supercontinent or affected by an enhanced accretion event? Gondwana Research, 15, 354-372.

Eriksson, P.G., Catuneanu, O., Nelson, D.R., Rigby, M.J., Bandopadhyay, P.C. \& Altermann, W. (2010a). Events in the Precambrian history of the Earth: problems in discriminating their global significance. Journal of Marine and Petroleum Geology.

Eriksson, P.G., Rigby, M.J. Bandopadhyay, P.C. \& Steenkamp, N.C. (2010b). The Kaapvaal Craton (South Africa): no evidence for a supercontinental affinity prior to $2.0 \mathrm{Ga}$ ? International Geology Review.

Gerdes, A. \& Zeh, A. 2009. Zircon formation versus zircon alteration - new insights from combined U-Pb and Lu-Hf in-situ LA-ICP-MS analyses, and consequences for the interpretation of Archean zircon from the Limpopo Belt, Chemical Geology, 261, 230-243

Holzer, L., Frei, R., Barton, J. M. and Kramers, J. D., 1998. Unravelling the record of successive high grade events in the Central Zone of the Limpopo Belt using $\mathrm{Pb}$ single phase dating of metamorphic minerals. Precambrian Research, 87, 87-115.

Jaeckel, P., Kroner, A., Kamo, S. L., Brandl, G. and Wendtk, J. I., 1997. Late Archaean to early Proterozoic granitoid magmatism and high-grade metamorphism in the central Limpopo belt, South Africa. Journal of the Geological Society of London, 154, 25-44. 
Kröner, A., Nemchin, A. A., Jaeckel, P., Hofmann, A., Brandl, G., and Pidgeon, R. T., 1998. Field relationships and age of supracrustal Beit Bridge Complex and associated granitoid gneisses in the Central Zone of the Limpopo Belt, South Africa. South African Journal of Geology, 101, 201-213.

Kröner, A., Jaeckel, P., Brandl, G., Nemchin, A. A. and Pidgeon, R. T., 1999. Single zircon ages for granitoid gneisses in the Central Zone of the Limpopo Belt, Southern Africa and geodynamic significance. Precambrian Research, 93, 299-337.

Ludwig, K. R. 1999. Isoplot/Ex, version 2.00: a geochronological toolkit for Microsoft Excel. Berkeley Geochronology Center Spec. Publ. 1a, Berkeley, 46 p.

Ludwig, K.R. 2000. SQUID 1.00: a user's manual. Berkeley Geochronology Center Spec. Publ. 2, Berkeley, $17 \mathrm{p}$.

McCourt, S. and Armstrong, R. 1998. SHRIMP U-Pb zircon geochronology of granites from the Central Zone of the Limpopo Belt, southern Africa: Implications for the age of the Limpopo Orogeny. South African Journal of Geology, 101 (4), 329-338.

Mezger, K. Rawnsley, C.M. Bohlen, S.R. Hanson, G.N. 1991. U-Pb garnet, sphene, monazite, and rutile ages: implications for the duration of high-grade metamorphism and cooling histories, Adirondack Mts., New York. Journal of Geology, 99 (3), 415-428.

Millonig, L., Zeh, A., Gerdes, A. \& Klemd, R. 2008. Late Archaean high-grade metamorphism in the Central Zone of the Limpopo Belt (South Africa): Petrological and geochronological evidence from the Bulai Pluton. Lithos, 103, 333-351.

Millonig, L., Zeh, A., Gerdes, A., Klemd, R., Barton Jr., J.M. 2010. Decompressional heating of the Mahalapye Complex (Limpopo Belt, Botswana): A response to Palaeoproterozoic magmatic underplating? Journal of Petrology 51 (3), pp. 703-729

Perchuk, L.L., van Reenan, D. D., Varlamov, D.A., van Kal, S.M., Tabatabaeimanesh, Boshoff, R., 2008. P-T record of two high-grade metamorphic events in the Central Zone of the Limpopo Complex, South Africa. Lithos, 103, 70-105.

Rigby, M.J. 2009. Conflicting P-T paths within the Central Zone of the Limpopo Belt: a consequence of different thermobarometric methods? Journal of African Earth Sciences, 54, 111-126.

Rigby, M.J., Brandl, G. \& Mouri, H. 2008a. P-T conditions and the origin of quartzo-feldspathic veins in metasyenites from the Central Zone of the Limpopo Belt, South Africa. South African Journal of Geology, $111,313-332$.

Rigby, M.J., Mouri, H. \& Brandl, G. 2008b. A review of the P-T-t evolution of the Limpopo Belt: constraints for a tectonic model. Journal of African Earth Sciences, 50, 120-132.

Rigby, M.J., Eriksson, P.G. \& Mavimbela, P.K. 2010. Comments on "Structural and compositional constraints on the emplacement of the Bushveld Complex" by B. Clarke, R. Uken \& J. Reinhardt. Lithos, $115,272-275$.

Williams, I. S. 1998. U-Th-Pb geochronology by ion microprobe. In McKibben, M. A.; Shanks, W. C. III and Ridley, W. I., eds. Applications of microanalytical techniques to understanding mineralizing processes, Rev. Econ. Geol. 7:1-35. 
Van Reenen, D.D., Boshoff, R., Smit, C.A., Perchuk, L.L., Kramers, J. D., McCourt, S., and Armstrong, R.A. 2008. Geochronological problems related to polymetamorphism in the Limpopo Complex, South Africa. Gondwana Research, 14, 644-662

Zeh, A., Klemd, R., 2008. Comments on P-T record of two high-grade metamorphic events in the Central Zone of the Limpopo Complex, South Africa. In: Perchuk, L.L., van Reenen, D.D., Varlamov, D.A., van Kal, S.M., Tabatabaeimanesh, Boshoff, R., (Eds.), Lithos, vol. 106, pp. 399-402.

Zeh, A., Klemd, R., Buhlmann, S., and Barton, J.M., 2004. Pro- and retrograde P-T evolution of granulites of the Beit Bridge Complex (Limpopo Belt, South Africa); constraints from quantitative phase diagrams and geotectonic implications. Journal of Metamorphic Geology, 22, 79-95.

Zeh, A, Holland, T.J.B., and Klemd, R., 2005a. Phase relationships in grunerite-garnet-bearing amphibolites in the system CFMASH, with applications to metamorphic rocks from the Central Zone of the Limpopo Belt, South Africa. Journal of Metamorphic Geology, 23, 1-17.

Zeh, A., Klemd, R., Barton, J. M., 2005b. Petrological evolution in the roof of the high-grade metamorphic Central Zone of the Limpopo Belt, South Africa. Geological Magazine 142, 229-240.

Zeh, A., Gerdes, A., Klemd, R. \& Barton J.M.Jr. 2007. Archean to Proterozoic crustal evolution of the Limpopo Belt (South Africa/Botswana): Constraints from combined U-Pb and Lu-Hf isotope zircon analyses, Journal of Petrology, 48, 1605-1639.

Zeh, A., Gerdes, A., Barton Jr., J.M., 2009. Archaean accretion and crustal evolution of the Kalahari Craton-the Zircon age and $\mathrm{Hf}$ isotope record of granitic rocks from Barberton/Swaziland to the Francistown Arc. J. Petrol. 50, 933-966. 
Table 1. Summary of SHRIMP U-Pb zircon data for sample RM06/49.

\begin{tabular}{|c|c|c|c|c|c|c|c|c|c|c|c|c|c|c|c|c|c|}
\hline $\begin{array}{l}\text { Grai } \\
\text { n. } \\
\text { Spot }\end{array}$ & $\begin{array}{l}\%^{206} P \\
b_{c}\end{array}$ & $\begin{array}{l}\text { pp } \\
\mathbf{m} \\
\mathbf{U}\end{array}$ & $\begin{array}{l}\text { pp } \\
\text { m } \\
\text { Th }\end{array}$ & $\begin{array}{l}{ }_{U}^{232} \mathrm{Th} /{ }^{238} \\
\end{array}$ & $\begin{array}{l}\text { ppm } \\
{ }^{206} \mathbf{P b}\end{array}$ & $\begin{array}{l}{ }^{(1)} \\
{ }^{206} \mathrm{~Pb} \\
\mathrm{U} \mathrm{Ag}\end{array}$ & & $\begin{array}{l}{ }_{207}^{(1)} \mathrm{Pb} / \\
\text { ge }\end{array}$ & $\mathbf{P b A}$ & $\begin{array}{l}\text { \%Di } \\
\text { s- } \\
\text { cor- } \\
\text { dant }\end{array}$ & $\begin{array}{l}{ }^{207} \mathbf{P b}^{*} /{ }^{206} \mathbf{P} \\
\mathbf{b}^{*}\end{array}$ & $\begin{array}{l} \pm \\
\%\end{array}$ & $\begin{array}{l}{ }_{\mathrm{U}}^{207} \mathbf{P b}^{*} /^{235} \\
{ }^{235}\end{array}$ & $\begin{array}{l} \pm \\
\%\end{array}$ & $\begin{array}{l}{ }_{\mathrm{U}}^{(1)} \mathrm{Pb}^{*} /^{238} \\
\end{array}$ & $\begin{array}{l} \pm \\
\%\end{array}$ & $\begin{array}{l}\text { Err } \\
\text { cor } \\
\text { r. }\end{array}$ \\
\hline 2.2 & 0.35 & 342 & $\begin{array}{l}113 \\
5\end{array}$ & 3.43 & 102 & $\begin{array}{l}191 \\
5\end{array}$ & $\begin{array}{l} \pm 2 \\
2\end{array}$ & 2020 & \pm 11 & 5 & 0.12438 & $\begin{array}{l}0.6 \\
3\end{array}$ & 5.932 & 1.5 & 0.3459 & 1.3 & .900 \\
\hline 2.3 & 0.42 & 344 & 797 & 2.39 & 109 & $\begin{array}{l}201 \\
5\end{array}$ & $\begin{array}{l} \pm 2 \\
1\end{array}$ & $\begin{array}{l}2011 . \\
9\end{array}$ & \pm 9.1 & 0 & 0.12381 & $\begin{array}{l}0.5 \\
1\end{array}$ & 6.263 & 1.3 & 0.3669 & 1.2 & .924 \\
\hline 3.1 & 0.39 & 306 & 974 & 3.29 & 92.6 & $\begin{array}{l}193 \\
7\end{array}$ & $\begin{array}{l} \pm 2 \\
2\end{array}$ & 2018 & \pm 8 & 4 & 0.12424 & $\begin{array}{l}0.4 \\
5\end{array}$ & 6.006 & 1.4 & 0.3506 & 1.3 & .945 \\
\hline 3.2 & 0.44 & 315 & $\begin{array}{l}112 \\
8\end{array}$ & 3.70 & 95.8 & $\begin{array}{l}194 \\
8\end{array}$ & $\begin{array}{l} \pm 2 \\
2\end{array}$ & $\begin{array}{l}2007 . \\
3\end{array}$ & \pm 8.5 & 3 & 0.12349 & $\begin{array}{l}0.4 \\
8\end{array}$ & 6.009 & 1.4 & 0.3529 & 1.3 & .939 \\
\hline 4.1 & 0.51 & 252 & 494 & 2.03 & 75 & $\begin{array}{l}190 \\
9\end{array}$ & $\begin{array}{l} \pm 2 \\
2\end{array}$ & $\begin{array}{l}2012 . \\
7\end{array}$ & \pm 9.7 & 5 & 0.12387 & $\begin{array}{l}0.5 \\
5\end{array}$ & 5.885 & 1.4 & 0.3446 & 1.3 & .925 \\
\hline 5.1 & 1.73 & 360 & $\begin{array}{l}103 \\
9\end{array}$ & 2.98 & 112 & $\begin{array}{l}196 \\
4\end{array}$ & $\begin{array}{l} \pm 2 \\
1\end{array}$ & 2003 & \pm 19 & 2 & 0.1232 & 1.1 & 6.049 & 1.7 & 0.3561 & 1.3 & .759 \\
\hline 6.1 & 0.50 & 325 & 957 & 3.04 & 97.3 & $\begin{array}{l}191 \\
7\end{array}$ & $\begin{array}{l} \pm 2 \\
1\end{array}$ & $\begin{array}{l}2005 . \\
4\end{array}$ & \pm 9.5 & 4 & 0.12336 & $\begin{array}{l}0.5 \\
4\end{array}$ & 5.891 & 1.4 & 0.3463 & 1.3 & .921 \\
\hline 7.1 & 0.41 & 310 & 909 & 3.03 & 94.3 & $\begin{array}{l}194 \\
7\end{array}$ & $\begin{array}{l} \pm 2 \\
1\end{array}$ & $\begin{array}{l}2008 . \\
6\end{array}$ & \pm 8 & 3 & 0.12358 & $\begin{array}{l}0.4 \\
5\end{array}$ & 6.007 & 1.4 & 0.3525 & 1.3 & .944 \\
\hline 7.2 & 0.85 & 305 & 916 & 3.10 & 92.5 & $\begin{array}{l}193 \\
5\end{array}$ & $\begin{array}{l} \pm 2 \\
2\end{array}$ & 2009 & \pm 12 & 4 & 0.12361 & $\begin{array}{l}0.6 \\
9\end{array}$ & 5.966 & 1.5 & 0.3501 & 1.3 & .883 \\
\hline 8.1 & 3.39 & 329 & $\begin{array}{l}101 \\
2\end{array}$ & 3.17 & 101 & $\begin{array}{l}190 \\
4\end{array}$ & $\begin{array}{l} \pm 2 \\
2\end{array}$ & 2026 & \pm 38 & 6 & 0.1248 & 2.2 & 5.91 & 2.5 & 0.3436 & 1.3 & .518 \\
\hline
\end{tabular}




\begin{tabular}{|c|c|c|c|c|c|c|c|c|c|c|c|c|c|c|c|c|c|}
\hline $\begin{array}{l}\text { Grai } \\
\text { n. } \\
\text { Spot }\end{array}$ & $\begin{array}{l}\%^{206} \mathbf{P} \\
b_{c}\end{array}$ & $\begin{array}{l}\text { pp } \\
\mathbf{m} \\
\mathbf{U}\end{array}$ & $\begin{array}{l}\text { pp } \\
\text { m } \\
\text { Th }\end{array}$ & $\begin{array}{l}{ }_{U}^{232} \mathrm{Th} /{ }^{238} \\
\end{array}$ & $\begin{array}{l}\text { ppm } \\
{ }^{206} \mathrm{~Pb}\end{array}$ & $\begin{array}{l}{ }^{(1)} \\
{ }^{206} \mathrm{~Pb} \\
\mathrm{U} \mathrm{Ag}\end{array}$ & & $\begin{array}{l}{ }_{207}^{(1)} \mathrm{Pb} / \\
\text { ge }\end{array}$ & bA & $\begin{array}{l}\% D i \\
\text { s- } \\
\text { cor- } \\
\text { dant }\end{array}$ & $\begin{array}{l}{ }^{207} \mathbf{P b}^{*} /{ }^{206} \mathbf{P} \\
\mathbf{b}^{*}\end{array}$ & $\begin{array}{l} \pm \\
\%\end{array}$ & $\begin{array}{l}{ }^{207} \mathbf{P b}^{*} /{ }^{235} \\
\mathrm{U}\end{array}$ & $\begin{array}{l} \pm \\
\%\end{array}$ & $\begin{array}{l}{ }^{206} \mathrm{~Pb}^{*} /{ }^{238} \\
\mathrm{U}\end{array}$ & $\begin{array}{l} \pm \\
\%\end{array}$ & $\begin{array}{l}\text { Err. } \\
\text { cor } \\
\text { r. }\end{array}$ \\
\hline 8.2 & 0.90 & 314 & $\begin{array}{l}101 \\
8\end{array}$ & 3.35 & 95.2 & $\begin{array}{l}193 \\
4\end{array}$ & $\begin{array}{l} \pm 2 \\
2\end{array}$ & 2014 & \pm 12 & 4 & 0.12399 & $\begin{array}{l}0.6 \\
7\end{array}$ & 5.982 & 1.5 & 0.3499 & 1.3 & .887 \\
\hline 9.1 & 4.84 & 354 & 886 & 2.58 & 111 & $\begin{array}{l}191 \\
4\end{array}$ & $\begin{array}{l} \pm 2 \\
2\end{array}$ & 2057 & \pm 49 & 7 & 0.127 & 2.8 & 6.05 & 3.1 & 0.3457 & 1.3 & .427 \\
\hline 9.2 & 1.86 & 316 & $\begin{array}{l}103 \\
2\end{array}$ & 3.37 & 97.9 & $\begin{array}{l}195 \\
0\end{array}$ & $\begin{array}{l} \pm 2 \\
2\end{array}$ & 2019 & \pm 28 & 3 & 0.1243 & 1.6 & 6.06 & 2.1 & 0.3533 & 1.3 & .632 \\
\hline 9.3 & 0.59 & 329 & $\begin{array}{l}138 \\
6\end{array}$ & 4.35 & 100 & $\begin{array}{l}194 \\
3\end{array}$ & $\begin{array}{l} \pm 2 \\
1\end{array}$ & $\begin{array}{l}1996 . \\
4\end{array}$ & \pm 9.6 & 3 & 0.12274 & $\begin{array}{l}0.5 \\
4\end{array}$ & 5.954 & 1.4 & 0.3518 & 1.3 & .922 \\
\hline 10.1 & 0.50 & 292 & 929 & 3.29 & 87.6 & $\begin{array}{l}192 \\
2\end{array}$ & $\begin{array}{l} \pm 2 \\
1\end{array}$ & 2012 & \pm 10 & 4 & 0.1238 & $\begin{array}{l}0.5 \\
6\end{array}$ & 5.931 & 1.4 & 0.3475 & 1.3 & .916 \\
\hline 11.1 & 0.49 & 303 & 659 & 2.25 & 91.6 & $\begin{array}{l}193 \\
8\end{array}$ & $\begin{array}{l} \pm 2 \\
1\end{array}$ & $\begin{array}{l}2005 . \\
3\end{array}$ & \pm 8.4 & 3 & 0.12335 & $\begin{array}{l}0.4 \\
7\end{array}$ & 5.964 & 1.4 & 0.3507 & 1.3 & .938 \\
\hline 11.2 & 2.15 & 148 & 323 & 2.26 & 45 & $\begin{array}{l}192 \\
1\end{array}$ & $\begin{array}{l} \pm 2 \\
5\end{array}$ & 2029 & \pm 28 & 5 & 0.125 & 1.6 & 5.98 & 2.2 & 0.3471 & 1.5 & .695 \\
\hline 12.1 & 0.56 & 267 & 451 & 1.74 & 79.7 & $\begin{array}{l}191 \\
3\end{array}$ & $\begin{array}{l} \pm 2 \\
2\end{array}$ & $\begin{array}{l}2012 . \\
1\end{array}$ & \pm 9.4 & 5 & 0.12383 & $\begin{array}{l}0.5 \\
3\end{array}$ & 5.897 & 1.4 & 0.3454 & 1.3 & .928 \\
\hline 14.1 & 0.68 & 285 & 942 & 3.42 & 87.5 & $\begin{array}{l}196 \\
1\end{array}$ & $\begin{array}{l} \pm 2 \\
2\end{array}$ & $\begin{array}{l}2019 . \\
9\end{array}$ & \pm 9.8 & 3 & 0.12437 & $\begin{array}{l}0.5 \\
5\end{array}$ & 6.098 & 1.4 & 0.3556 & 1.3 & .920 \\
\hline 14.2 & 0.99 & 99 & 151 & 1.57 & 29.6 & $\begin{array}{l}190 \\
6\end{array}$ & $\begin{array}{l} \pm 2 \\
9\end{array}$ & 2012 & \pm 25 & 5 & 0.1238 & 1.4 & 5.87 & 2.2 & 0.344 & 1.7 & .782 \\
\hline 15.1 & 1.69 & 278 & $\begin{array}{l}106 \\
9\end{array}$ & 3.98 & 82.8 & $\begin{array}{l}189 \\
1\end{array}$ & $\begin{array}{l} \pm 2 \\
2\end{array}$ & 2003 & \pm 20 & 6 & 0.1232 & 1.1 & 5.791 & 1.7 & 0.341 & 1.3 & .761 \\
\hline
\end{tabular}




\begin{tabular}{|c|c|c|c|c|c|c|c|c|c|c|c|c|c|c|c|c|c|}
\hline \multirow{2}{*}{\begin{tabular}{|l|}
$\begin{array}{l}\text { Grai } \\
\text { n. } \\
\text { Spot }\end{array}$ \\
20.1 \\
\end{tabular}} & \multirow{2}{*}{\begin{tabular}{|l}
$\begin{array}{l}\mathbf{\%}^{206} \mathbf{P} \\
\mathbf{b}_{\mathbf{c}}\end{array}$ \\
3.64
\end{tabular}} & \multirow{2}{*}{$\begin{array}{l}\text { pp } \\
\mathbf{m} \\
\mathbf{U} \\
60\end{array}$} & \multirow{2}{*}{$\begin{array}{l}\mathbf{p p} \\
\mathbf{m} \\
\mathbf{T h}\end{array}$} & \multirow{2}{*}{$\begin{array}{l}\mathbf{U}^{232} \mathbf{T h} /{ }^{238} \\
1.89\end{array}$} & \multirow{2}{*}{$\begin{array}{l}\text { ppm } \\
{ }_{*}^{206} \mathrm{~Pb} \\
18.5\end{array}$} & \multicolumn{2}{|c|}{$\begin{array}{l}(1) \\
{ }^{206} \mathrm{~Pb} /{ }^{238} \\
\text { U Age }\end{array}$} & \multicolumn{2}{|c|}{$\begin{array}{l}{ }^{207} \mathrm{~Pb} /{ }^{206} \mathrm{PbA} \\
\text { ge }\end{array}$} & \multirow{2}{*}{$\begin{array}{l}\begin{array}{l}\% \text { Di } \\
\text { s- } \\
\text { cor- } \\
\text { dant }\end{array} \\
4\end{array}$} & \multirow{2}{*}{$\begin{array}{l}{ }_{{ }^{207}}^{(\mathbf{1})} \mathbf{P b}^{*} /{ }^{206} \mathbf{P} \\
0.1232\end{array}$} & \multirow{2}{*}{$\begin{array}{l} \pm \\
\% \\
\end{array}$} & \multirow{2}{*}{\begin{tabular}{|l}
${ }^{207} \mathbf{P b}^{*} /^{235}$ \\
$\mathbf{U}$
\end{tabular}} & \multirow{2}{*}{$\begin{array}{l} \pm \\
\% \\
3.4\end{array}$} & \multirow{2}{*}{$\begin{array}{l}{ }^{206} \mathbf{P b}^{*} / /^{238} \\
\mathbf{U} \\
0.3456\end{array}$} & \multirow{2}{*}{\begin{tabular}{|l|}
$\begin{array}{l} \pm \\
\%\end{array}$ \\
2.1
\end{tabular}} & \multirow{2}{*}{ 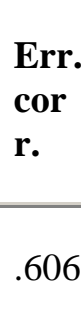 } \\
\hline & & & & & & $\begin{array}{l}191 \\
4\end{array}$ & $\begin{array}{l} \pm 3 \\
4\end{array}$ & 2003 & \pm 48 & & & & & & & & \\
\hline 21.1 & 0.33 & 324 & $\begin{array}{l}112 \\
0\end{array}$ & 3.57 & 96.1 & $\begin{array}{l}190 \\
6\end{array}$ & $\begin{array}{l} \pm 2 \\
1\end{array}$ & $\begin{array}{l}2006 . \\
1\end{array}$ & \pm 7.1 & 5 & 0.12341 & 0.4 & 5.855 & 1.3 & 0.3441 & 1.3 & .954 \\
\hline
\end{tabular}

Errors are 1-sigma; $\mathrm{Pb}_{\mathrm{c}}$ and $\mathrm{Pb}^{*}$ indicate the common and radiogenic portions, respectively.Error in Standard calibration was $0.30 \%$ (not included in above errors but required when comparing data from different mounts). (1) Common Pb corrected using measured ${ }^{204} \mathrm{~Pb}$. 